Article

\title{
Pansacramentalism, Interreligious Theology, and Lived Religion
}

\author{
Hans Gustafson $(\mathbb{D}$ \\ College of Arts and Sciences, University of St. Thomas, 2115 Summit Avenue, Mail 57P, St. Paul, MN 55105, \\ USA; hsgustafson@stthomas.edu
}

Received: 21 May 2019; Accepted: 26 June 2019; Published: 28 June 2019

\begin{abstract}
Opening with a philosophical definition of sacrament(ality) as a mediator (mediation) of the sacred in the concrete world, this article offers pansacramentalism as a promising worldview-especially for those rooted in or emerging from the Christian traditions (since, for them, the language of sacramentality may have a stronger resonance)—for bringing together interreligious theology and data mined by Lived Religion approaches to the study of religion. After articulating the concept of pansacramentalism and emphasizing interreligious theology as an emerging model for doing theology, growing trends and changing sensibilities among young people's religious and spiritual lives (e.g., the "Nones") is considered insofar as such trends remain relevant for making contemporary theology accessible to the next generation. The article then considers the intersection of pansacramentalism and interreligious theology, especially the issue of determining sacramental authenticity. To explain how this challenge might be met, Abraham Heschel's theology of theomorphism is offered as but one example as a nuanced means for determining sacramental authenticity of the sacred in the world. Turning to "Lived Religion" approaches, rationale is offered for why pansacramentalism and interreligious theology ought to be taken seriously in the contemporary world, especially considering recent data about the nature of contemporary religious identities among young people living in the West.
\end{abstract}

Keywords: pansacramentalism; sacramentality; interreligious; lived religion; interreligious studies

\section{Introduction}

Opening with a philosophical definition of sacrament(ality) as a mediator (mediation) of the sacred in the concrete world, this article offers pansacramentalism as a promising worldview-especially for those rooted in or emerging from the Christian traditions (since, for them, the language of sacramentality may have a stronger resonance)—for bringing together interreligious theology and data mined by Lived Religion approaches to the study of religion. Perry Schmidt-Leukel's vision of interreligious theology is utilized, given its contemporary relevance, the depth with which it has been presented (earning a multi-lecture platform on the prestigious Gifford Lectures) (Schmidt-Leukel 2015), its resonance with pansacramentalism, and for its potential appeal to the growing trends and changing sensibilities among younger people today in the Western world (i.e., the so-called "Nones" and religiously unaffiliated who make-up the fastest growing religious identity in the West).

After articulating the concept of pansacramentalism and emphasizing interreligious theology as an emerging model for doing theology, this article accounts for the growing trends and changing sensibilities among young people today (e.g., the "Nones"). No doubt, such an exercise remains fruitful for any contemporary theological proposal, especially those that strive to remain grounded in traditional language and concepts such as sacramentality. The religious and spiritual lives among the next generation are worth considering here, especially insofar as the implications of pansacramentalism extend to this rapidly emerging group in the Western world. 
Turning to the intersection of pansacramentalism and interreligious theology, the issue of determining sacramental authenticity is raised. To explain how this challenge might be met, an example is provided by employing Abraham Heschel's theology of theomorphism as a nuanced means for determining sacramental authenticity of the sacred in the world. However, ultimately, it is argued, that such criteria ought to be generated by religious traditions, communities, and individuals themselves. The example of Heschel's theology might be one such approach for those who assent to his theological vision and categories. Though Heschel comes out of the Jewish tradition, such an approach (and indeed the pansacramentalism and interreligious theology, for that matter) certainly need not be considered an Abrahamic pursuit. In fact, it might be argued that these approaches are more naturally at home among non-Abrahamic traditions.

Finally, turning to "Lived Religion" approaches to the study of religion and religious identity, rationale is given for why pansacramentalism and interreligious theology ought to be taken seriously in the contemporary world. In other words, it is hardly surprising that a pansacramental worldview, which maintains all things as potentially sacramental, coupled with the doing of theology interreligiously, resonates with recent data about the nature of contemporary religious identities, especially among young people living in the West, as reported by scholars of Lived Religion.

\section{Sacramental Functionality and Pansacramentalism}

In order to properly address pansacramentalism and interreligious theology in the greater scope of this special issue on sacramental theology, this article commences with a preliminary word about the term "sacrament." To most ears (especially in the Western world, and especially to non-Catholics), the term sacrament often connotes Catholicism. Of course, the term is used well beyond Catholicism (in most Protestant traditions), and beyond Christianity at that. In fact, it even predates Christianity tracing its roots to two pre-Christian era terms: sacramentum (Latin) and mysterion (Greek). ${ }^{1}$ At the turn of the third century, Tertullian applied sacramentum to Christian rituals in order to articulate their sacredness (e.g., Baptism). Later, it gained popularity to reference any sacred symbol or ceremony, prior to which it was mostly only used to consecrate legal and financial pledges made in the Roman temple or the swearing oaths in legal, religious, or military contexts (Martos 2001, p. 4; Gustafson 2016a, p. 54; 2019). In the New Testament, Paul employs mysterion to refer to Baptism and the Lord's Supper. However, in the greater Greek context, the term was regularly used to denote secret sacred rituals understood to symbolically reveal hidden knowledge. This is, of course, in reference to the Greek gnostic mystery cults, in which the rituals were interpreted to instantly reveal a mystery. As such, mysteria unveil ultimate reality. Drawing on both terms, sacramentum and mysterion, the dominant Christian understanding, which later emerged, made prominent an understanding of sacrament that refers to both the communal dimension of sacramentum (e.g., swearing of an oath between persons) and the individual dimension of mysterion (i.e., the instant unveiling of hidden knowledge of sacred significance) (Gustafson 2016a, p. 54; 2019).

A fundamental function of sacraments is that they serve as symbols (mediators) of ultimate (or religious) significance. Symbols mediate between things: between the particular and the universal (that is, they make the universal particular, but they also make the particular universal). Symbols, understood this way, bring into the present that which they symbolize. Sacraments are religious symbols or symbols of ultimacy. This is to say that sacraments symbolize, or bring into the present, the sacred (however one might construe it). Below is a three-fold understanding of sacraments as religious symbols of ultimate significance:

1 Joseph Martos writes: “There were sacraments in the Greek and Roman religious world of early Christianity. There were the formal sacraments of the official state religion: oaths and offerings, oracles and auguries, public festivals and family devotions. There were also the sacraments of the mystery religions: symbolic rituals that dramatized deeper religious meanings for those who sought them" (Martos 2001, p. 23; also quoted in Gustafson 2019). 
1. Sacraments are not just signs. This is to say that sacraments, like signs, point beyond themselves to something sacred or ultimate, but they also point inward (unlike signs). More accurately, sacraments make present, via self-expression, that which they symbolize.

2. Sacraments concretize the sacred. Employing corporeal material worldly elements, sacraments make present (concretize) the sacred in the present world. Pansacramentalism, as discussed below, maintains the potential for all things to function as sacraments insofar as they facilitate the concretization (the making present) of the sacred in the contemporary world. As such, a sacrament makes something that is particular (material element) universally relevant by revealing a hidden depth. Put another way, sacraments universalize the significance of particular material elements by using them to reveal something of sacred ultimate significance.

3. Sacraments invite participation. They hold the potential to draw people into their depths by revealing something ultimate and transformative. For instance, art (e.g., music, film, literature) and nature provide some of the most obvious examples of sacramental experience, in which there exists the potential to move people to realize something about the world, themselves, and/or their relation to the sacred in an ultimate and transformative way. Such experiences, when unpacked, are often understood to have unveiled something hidden or mysterious (mysterion) to a particular person or community, and as such, prompt the making of an oath or pledge (sacramentum) to chart a new path in one's life accordingly. ${ }^{2}$

With this basic framework of sacramental functionality in mind, I turn to the concept of pansacramentalism, a concept I first encountered in the work of Martin Buber. He employs the term 'pansacramentalism' to illuminate various distinct features of Hasidic sacramentality (Buber 1966, p. 178). I am unaware of any earlier usage, although Christian theological echoes exist in Karl Rahner's influential sacramental vision and Christopher C. Knight's "pansacramental naturalism" (Knight 2001), not to mention conceptual analogs that most certainly exist in non-Abrahamic traditions (e.g., Hindu-Brahmanic visions of God-world relatedness). Pansacramentalism is suggested here due to the Christian —or perhaps Abrahamic — origins of this special issue, which focuses on sacramental theology. However, an argument might be made that there is nothing intrinsic to the term, and other terms might be better suited for the task (see note 28).

The context of panentheism (or Panentheistic Pansacramentality ${ }^{3}$ ) is relevant for pansacramentalism. It is a concept that has pushed philosophical theologians and philosophers of religion to wrestle with similar enduring questions and challenges, especially the question of how the sacred and world are related. The term panentheism came into popular German (Allingottlehre) usage in 1829 by Karl Krause and was first used in English by William Ralph Inge's in 1899 (Inge 1948, p. 121; cf. Brierley 2004), however, the concept it refers to is hardly novel with antecedents found from Plato, Plotinus, Ramanuja to the present day in several traditions. Panentheism literarily refers to the claim that all is in theos or the divine, yet the divine is not exhausted by all things. In simpler terms, although God is in the world and the world is in God, God remains more than, and thus transcends, the world as such. The Oxford Dictionary of the Christian Church defines it as "the belief that the Being of God includes and penetrates the whole universe so that every part of it exists in Him, but (as against pantheism) that His Being is

2 A popular example of this is in the Christian tradition is Henri Nouwen's reflection on seeing Rembrandt's "The Return of the Prodigal Son" for the first time. It moved Nouwen to question his vocation and place in life and, in Nouwen's words "set in motion a long spiritual adventure that brought me to a new understanding of my vocation and offered me new strength to live it" (Nouwen 1994, p. 3). "Natural wonders, and other people are examples of potential sacraments demanding others to participate with them.... Standing at the base of a mountain, sitting on the shore of the sea, listening to a powerful ballad, viewing a moving piece of art, or gazing into the depths of another's eyes are all potential sacramental moments that beckon the person inward to reflect on her place in the world. In this manner, sacraments provoke action, foster self-reflection, and invite self-transformation" (Gustafson 2019).

3 Variations of panentheistic pansacramentality, and what follows in this section, were first presented in (Gustafson 2013; 2016a, pp. 288-93), and (Gustafson 2019). Panentheism posits all things in the divine (theos), yet also usually declares the divine to be more than all things. As such, panentheists wrestle with the question of how the sacred dwells in all things, and how all things dwell in the sacred. 
more than, and is not exhausted by, the universe" (Panentheism n.d.). Christian thinkers who endorse it, often praise its promise as an alternative to pantheism (all-is-God as such) and an acosmic classical theistic worldview that radically separates the divine and world.

Pansacramentalism might be understood as either a particular version of panentheism (since there are several) and/or an attempt to articulate panentheism's core claim that all things exist in God, yet God remains more than all things. To put it simply, pansacramentalism refers to a worldview that maintains all things (earthly, corporeal, spiritual, or otherwise) as holding the potential to function as mediators (symbols) of the sacred (e.g., the divine, God[s]), etc.). The value pansacramentalism holds over panentheism is its particular vision for how all things function as sacramental mediators of the divine in the world. Pansacramentalism, perhaps by avoiding some of the excess (and oft misunderstood) philosophical baggage that accompanies panentheism in its diverse usage, allows for an unapologetic (and hopefully appealing) valuing of particularities in the concrete world, which not only includes traditional religious rituals and practices, but also the less-often recognized mundane and everyday acts of spirituality and experiences of the sacred. Pansacramentalism articulates an understanding of the relations between the world, the sacred, and persons that rests on, what I refer to as, the "principle of panentheistic pansacramentality" ( $\mathrm{P}^{3}$, for shorthand). This principle maintains "all things sacramentally exist in the sacred, and the sacred sacramentally exists in all things" (Gustafson 2019). $P^{3}$ serves panentheism, I suppose, by providing a theological response to the question of how all things exist in the sacred by maintaining that they (all things) do so sacramentally (if the above framework for sacramental functionality is assumed). It is beyond the scope of this article to dwell too invasively on precisely how the pansacramental relationship between the sacred and the world (all things) ought to be understood in a panentheistic manner. ${ }^{4}$ Rather, it is sufficient to posit the basic underlying assumption of pansacramentalism that all things serve as potential mediators of the divine in some manner.

\section{The Emergence of Interreligious Theology}

The proposal this chapter makes is that pansacramentalism provides a promising worldview for engaging interreligious theology. Interreligious theology, for the purposes of this article, presupposes, with Perry Schmidt-Leukel, a broad understanding of theology to include an intellectual reflection on both theistic and nontheistic traditions (Schmidt-Leukel 2017, p. 8), including discourse between, among, and within Abrahamic, Dharmic, and non-religious secular traditions. In fact, the bulk of Schmidt-Leukel's interreligious theology has been worked out in the context of the Buddhist and Christian traditions. Needless to say, interreligious theology is by no means an inter-Abrahamic enterprise, but extends well beyond it and perhaps is even more naturally at home within and between non-Abrahamic traditions. ${ }^{5}$ The most precise working definition for interreligious theology comes from Schmidt-Leukel, a scholar doing some of the most serious and significant theoretical work in this area today. He defines interreligious theology as "the form that theology assumes when it takes religious truth claims seriously, those of one's own religious tradition and those of all others. Taking them seriously means to search for possible truth in all of the religious testimonies" (Schmidt-Leukel 2017, p. 13). Keith Ward, with his monumental five-volume series, ${ }^{6}$ and Wilfred Cantwell Smith, might be considered forerunners to the interreligious theology espoused by Schmidt-Leukel and Ephraim Meir; all worth recognition here.

4 For a more exhaustive dissection of this pansacramental vision embedded in a panentheistic context, see metaphors of (a) the world as God's body in (Ward 2004); and (b) the relationship between art and artist (house and builder), and the relationship between child and parent (baby and mother) in (Gustafson 2019).

5 E.g., Certain theories of tantra/tantric traditions within Hinduism and Buddhism, which date back to the 5th century C.E., might be interpreted to articulate a spirit of interreligious theology and perhaps even pansacramentality. The word tantra is derived from Sanskrit and means to "weave" as in the interweaving of various traditions together.

6 (Ward 1994, 1996, 1998, 2000, 2008). 
Wilfred Cantwell Smith's well-known "world theology", presented in his Towards a World Theology (Smith [1981] 1989), takes seriously the project of doing theology interreligiously (or transreligiously ${ }^{7}$ ) insofar as he urges the global community to recognize the time has come to recognize our shared religious story embedded in, what he refers to as, "faith" (a universal shared among all traditions but expressed through differing and particular "beliefs." 8 Smith's world theology points to the abandonment of particular religious theological designators such as "Christian" theology or "Islamic" theology. Rather, world theology serves as a model of theological inquiry that draws on all religious traditions in order to elucidate the universal character of "faith", despite the particular manifestations of the beliefs emanating out of the religious, worldview, and lifeway traditions of the globe, past and present. A "world" theology such as this, it seems, envisions a collaborative system of diverse beliefs that is "continually developed by people from around the world, and of all religious identifications, who remain consciously aware of the one history of universal faith that undergirds all separate religions (with their distinct particular beliefs)" (Gustafson 2016b, p. 249). If theological accounts are to be taken seriously at all, they must, at the very least, account for each other, Smith argues. Theology ought to remain in the continual state of revision in light of contemporary discovery. Notable instances include the emergence of Greek philosophy (e.g., Thomas Aquinas' Christian theology in light of and dialogue with Aristotelian metaphysical philosophy, categories, and language) the discovery of the modern scientific method. Just as these major worldly influences pushed theologians to sharpen and revise their thought (for the better), Smith argues "the time has come for the reality of religious plurality to encourage a similar constructive rethinking as well" (Gustafson 2016b, p. 249), ${ }^{9}$ without which theology will die (or just be ignored).

Keith Ward envisions that,

The great religious traditions are histories of developing reflection on the primal disclosures that constitute a tradition. In their meeting, the opportunity exists for conversations in which each tradition is modified by its greater empathy for the insights embodied in other traditions. It is in this way that diversity, and the freedom it requires, can be helpful to the discovery of the partiality in one's own views, and thus of a more expansive truth (Ward 2007, p. 198). ${ }^{10}$

This vision does not perhaps go as far as Smith's "world theology", which proposes a truly interreligious theology insofar as it seemingly reserves more space for the particularity, uniqueness, and separation of one's own religious tradition. Ward, a committed Christian, demonstrates a rigorous investigation of theological issues important to Christianity and the understanding of Jesus for Christians by entering into conversation with the religious traditions of the world. Unlike Smith's "world theology", Ward's is one of Christian theology, especially since he begins with categories important to the Christian tradition (e.g., revelation, creation, community). Ward's disposition towards the overarching nature and benefit of this approach is instructive here for our consideration of pansacramentality and interreligious theology. He professes that "once an understanding of faith as acceptance of exclusively correct propositions is given up, one can no longer simply say that the Christian faith has the only truth and that all others are wrong. If faith is a response to a disclosure of the divine in this community, then why should there not be different disclosures of the divine in other communities?" (Ward 2002, p. 51) ${ }^{11}$ Such an attitude represents an approach towards doing theology interreligiously and to finding the sacred in all things including other religions.

7 See (Martin 2016); contributions from Wesley J. Wildman, John L. Thatamanil, Peter Feldmeier, J.R. Hustwit, Rory McEntee, Jon Paul Sydnor, Jeanine Diller, Hans Gustafson, Christopher Denny, Jonathan Weidenbaum, and Anthony J. Watson.

8 I am indebted to Jim Fredericks' examination of Wilfred Cantwell Smith's theology in Fredericks, 1999, pp. 79-89; also referenced in (Gustafson 2016b, pp. 248-49).

9 Citing (Smith 2001, pp. 47-48).

10 Also quoted in (Gustafson 2016b, p. 249) and (Gustafson 2016a, p. 176).

11 Also quoted in (Gustafson 2016b, p. 249). 
Ephraim Meir and Perry Schmidt-Leukel represent perhaps the two most rigorous contemporary thinkers working to articulate a theory of interreligious theology. Meir defines interreligious theology as "the reflection on the conditions for a dialogue in which partners learn from each other and appreciate or criticize each other. Not only mutual enrichment, but also mutual change could be the result of the interreligious encounter" (Meir 2015, p. 178). An aspect of Meir's vision of particular interest to this article is his emphasis on the lived religious experience. His vision of interreligious theology "does less work with official representatives of religious institutions-which is frequently boring and without depth - than with learning in bookless moments from and with people who live and think differently" (Meir 2015, pp. 178-79). It "deals with religious diversity and is part of the reflection upon communities in which multiculturality is lived.... It takes lived religiosity in a particular context as a basis" (Meir 2015, p. 179). As such, Meir's interreligious theology seeks out and grounds reflection in the messy complicated entanglements of religious and cultural identities that take place within, between, and among religious individuals and communities. He writes, "this new kind of theology does not work 'from above' with identities fixed once and for all, but 'from below' with an analysis of concrete situations in which there are all kinds of belonging" (e.g., dual-belonging, multiple religious belonging, religious hybridity, bricolage, assemblage, syncretism, etc.) (Meir 2015, p. 179).

"Interreligious Theology", then, as understood by Schmidt-Leukel and endorsed in this article, can be briefly summarized with four "principles" or "starting points" (Schmidt-Leukel 2017, p. 130). First, interreligious theology is only possible when it operates on the assumption that theological truth can be found beyond one's own tradition. ${ }^{12}$ Second, the process of seeking theologically relevant truth must be "guided by the conviction that ultimately, all truth - wherever and in whatever form it might be found-must be compatible." ${ }^{\prime 13}$ This eliminates exclusivist approaches from being interreligious theology because there is no real openness to the possibility of discovering truth or insights from other traditions. Third, interreligious theology must be done interreligiously; that is, an interreligious theologian seeks out encounter, engagement, and discourse with individuals and communities living out other religious traditions, worldviews, and lifeways. ${ }^{14}$ Fourth and finally, interreligious theology is "an open process;" that is, it is never finished, always in process, and "it will, therefore, be impossible for any single person to produce something like a completed interreligious theology" (Schmidt-Leukel 2017, p. 128). ${ }^{15}$

In addition to these four starting points (principles), Schmidt-Leukel argues that interreligious theology ought to methodologically proceed as perspectival, imaginative, comparative, and constructive. The interreligious theologian's perspective is one of integration. She remains confessional in the sense of being committed, attached, rooted, somewhere, but remains open to and prepared to revise, change, and transform her perspective when called to do so. However, "the real challenge for an interreligious theology arises not from the question of how many other perspectives one may be able to understand, but from the peculiar nature of religious perspectives, that is, from the insight into the close interweaving of religious beliefs with confessional stances" (Schmidt-Leukel 2017, p. 141). Interreligious theology needs to be imaginative because in order to empathize with other views, to understand them, to walk a mile in another's shoes, or, as Wilfred Cantwell Smith was fond of saying, that in order to "understand Buddhists, we must not look at something called Buddhism but at the world so far as possible through Buddhist eyes" (Smith [1981] 1989, p. 82) ${ }^{16}$ we must be able to imagine the other's view in order to understand the "reasons that motivate the other in his or her belief. It means to put oneself imaginatively into the other's shoes" (Schmidt-Leukel 2017, p. 142). Interreligious

12 I.e., Schmidt-Leukel refers to this principle as "a theological credit of trust" (Schmidt-Leukel 2017, pp. 130-33).

13 I.e., Schmidt-Leukel refers to this principle as "the unity of reality" (Schmidt-Leukel 2017, pp. 133-36).

14 I.e., Schmidt-Leukel refers to this principle as "tied to interreligious discourse" (Schmidt-Leukel 2017, pp. 136-38).

15 Schmidt-Leukel refers to this principle as the "processual, essential incomplete nature" of interreligious theology (Schmidt-Leukel 2017, pp. 138-39).

16 Also quoted in (Schmidt-Leukel 2017, p. 143). 
theology ought to take place comparatively; that is, the spirit of comparative theology (i.e., learning about one's own tradition in, and perhaps transformed by, engagement with and learning about other traditions) ${ }^{17}$ ought to be utilized insofar as the interreligious theologian embraces the likelihood that her self-understanding and understanding of her own religious tradition "may change if it is seen in light of the religious other" (Schmidt-Leukel 2017, p. 143). Finally, interreligious theology proceeds via a constructive methodology in that it must come to terms with (i.e., get over the fear of) syncretism, 18 and therefore embrace the possibility (and probability) that "such revisions may often take the form of reinterpretation or reconstruction" (Schmidt-Leukel 2017, p. 144). With pansacramentalism and the contemporary method of interreligious theology proposed above, I now turn to the significant trend of the religiously unaffiliated in the West, especially insofar as they make up a growing segment of young people. Their presence remains relevant, and increasingly so, for looking to multiple traditions for theological insights and religious wisdom.

\section{Young American Nones and Somes}

Turning to recent trends in religious identities, especially in the West, the sociological data shows growth in multiple and dual religious identities, hybridity, and religious bricolage (especially among younger generations). A group of particular significance is the emergence of the religiously unaffiliated (or the so-called "nones"), which today make up approximately one-third of all young adults (born between 1981 and 1996) in the United States. Accounting for the growing trends and changing sensibilities among younger people today is fruitful for any contemporary theological proposal, especially those that strive to ground their projects in traditional language and concepts (e.g., sacramentality). Therefore, it is worth considering what the implications of pansacramentalism are for the fastest growing religious identity in the West.

Elizabeth Drescher's recent study (Drescher 2016) on the spiritual lives of this group in the United States reveals that they reside equally throughout all regions of the country (with slightly fewer in the southeast) and are relatively equally represented among men and women. Drescher's data construct the stereotypical profile of an American None as someone "who is younger, urban, white, a bit more likely to be male than female, slightly more than most Americans to have had at least some college education, but no more likely to have completed college or graduate school" (Drescher 2016, p. 20). The most significant stereotype (worth considering) is that Nones are usually under 35 years of age.

However, even though America has followed many Western European nations in continuing its trajectory of becoming more secular and less religious, since the 1960s, it is not the case that the American non-religious have become more anti-religious and anti-spiritual, and it is certainly not the case that this significant young group of religiously unaffiliated are monolithic. Rather, they represent a diverse group of people with tendencies towards religion and spirituality also found in young Americans who do identify with a particular religious tradition. The recent work of sociologist Richard Flory is helpful here (Flory 2017). He stresses the internal diversity of this group, which is often overlooked (as it is with most religious groups). Some have parsed the religiously unaffiliated into atheists, agnostics, "no religious preference", "nothing", "spiritual but not religious", and others. However, Flory argues these subcategories remain too simplified. More importantly, and for this article,

17 The "the term 'Comparative Theology' has been used in various ways, or applied to different types of engagement with religious plurality" by different thinkers in different contexts since 1700 (Cornille 2019, p. 9). Proper assessments of comparative theology include the recently published important works by Hedges (2017a) and Cornille (2019). As it particularly relates to this article on interreligious theology, and Schmidt-Leukel's interreligious theology vis-à-vis comparative theology and theology of religions, a clear discussion is offered by Hedges (2017a, pp. 5-23). For a poignant discussion on "the difference between comparative and interreligious theology", see (Leirvik 2018).

18 Schmidt-Leukel writes, "I do not see any problems with syncretism as such. All great religions are, after all, the produce of syncretistic processes ... Currently one of the biggest obstacles to the idea of conscious interreligious borrowing seems to be the widespread fear of syncretism. Yet this fear ignores the syncretistic of all major religious traditions: They originated from and further developed under the influence of various other religions"' (Schmidt-Leukel 2017, pp. 138, 144-45; 2009, pp. 67-89). 
such categories do not always do justice to the Nones' complex relationships to the divine (God, Gods, or the transcendent) and religious institutions. Indeed, do not all people, regardless of their religious identity, have rather complex relations to God(s) and religious institutions? Thus, the same might be said for many young Americans who do identify with religion. Yes, for some Nones "religion has no place in their lives; others may be marginally interested in religion but rarely if ever attend services" (Flory 2017). However, the group overall still claims that religion does indeed have relevance in their lives, with many who attend religious services, pray and mediate, and believe in God(s). ${ }^{19}$ Perhaps this is one driver behind the rise in the category of "Spiritual But Not Religions" (SBNR), which allows one to leave room for religiosity in their lives yet provides some distance from institutional affiliation.

Unlike their Western European counterparts, the young religiously unaffiliated in America are still on the whole religious, if "being religious" here refers to a belief in God, attending religious services, and praying. In fact, by these standards, American "nones" are more religious than Western European Christians (see Figure 1) (Pew Research Center 2018). In other words, SBNRs and the religiously unaffiliated in the United States are often misunderstood. ${ }^{20}$ Interestingly, Drescher situates the Nones (which includes SBNRs) in relation to "Somes", the religiously affiliated. This is relevant for this article because she discovered that the "spiritualities of Nones are hardly distinct or isolated from the spiritualities of Somes with whom they share much of their everyday lives" (Drescher 2016, p. 8). For instance, those who share similar demographic characteristics as Nones, but are Somes (that is, those who do religiously identify), are becoming more likely to identify, practice, participate or belong to more than one tradition. In other words, it is becoming slightly more common in the West, especially among young people, to have multiple religious belongings, practices, and/or identities (e.g., dual belonging, religious hybridity, bricolage, etc.). This comports with my experience in the classroom as students seem to be more comfortable with confronting the complexity of their identity, especially their religious identity as being multiple and attracted to multiple traditions, or, at the very least, attracted to practices from various traditions. ${ }^{21}$

This brief detour into the sociological trends of young American Nones and Somes shows the horizon towards which young people seem to be moving when it comes to interfacing with the growing religious diversity of their world and the manifold ways to religiously identify that stem from it. Perhaps, and needless to say, Schmidt-Leukel's prediction that "it seems rather likely that future theology to a large extent [will] take the form of 'interreligious theology'" (Schmidt-Leukel 2017, p. 129) and the emphasis in this article on the category of pansacramentalism, may turn out to be rather appealing for young people who have, at the very least, some interest in the categories of theology and sacramentality (both of which have some Christian, or at least Abrahamic, roots).

19 Note: there are, of course, those who continue to pray, meditate, and attend religious services not due to belief in these activities "as having any particular religious or spiritual content" (Flory 2017), rather they might understand these things to be healthy habits that lead to a more fulfilling life akin to attending a community gathering, being social, exercising, or eating a healthy diet.

20 Drescher argues that Nones are often misunderstood, sometimes labeled "superficial, uncommitted, narcissistic" (Drescher 2016, p. 48; see also p. 5).

21 This latter phenomenon, engaging in varying religious practices from several religions at different times to meet a variety of needs, is what Paul Hedges refers to as "Strategic Religious Participation in a Shared Religious Landscape." Less scandalous in Chinese and Asian contexts, it provides more space for participants to make suitable choices that are meaningful for them within their regional religious landscape (or "religious ecology"). It is understood by its residents as a "Shared Religious Landscape" in which traditions are "not composed of hermetically sealed borders of mutually exclusive religious belief-based territories" (Hedges 2017b, pp. 63, 51). 


\section{Compared with U.S. adults, relatively few Western European Christians and religiously unaffiliated people are religiously observant}

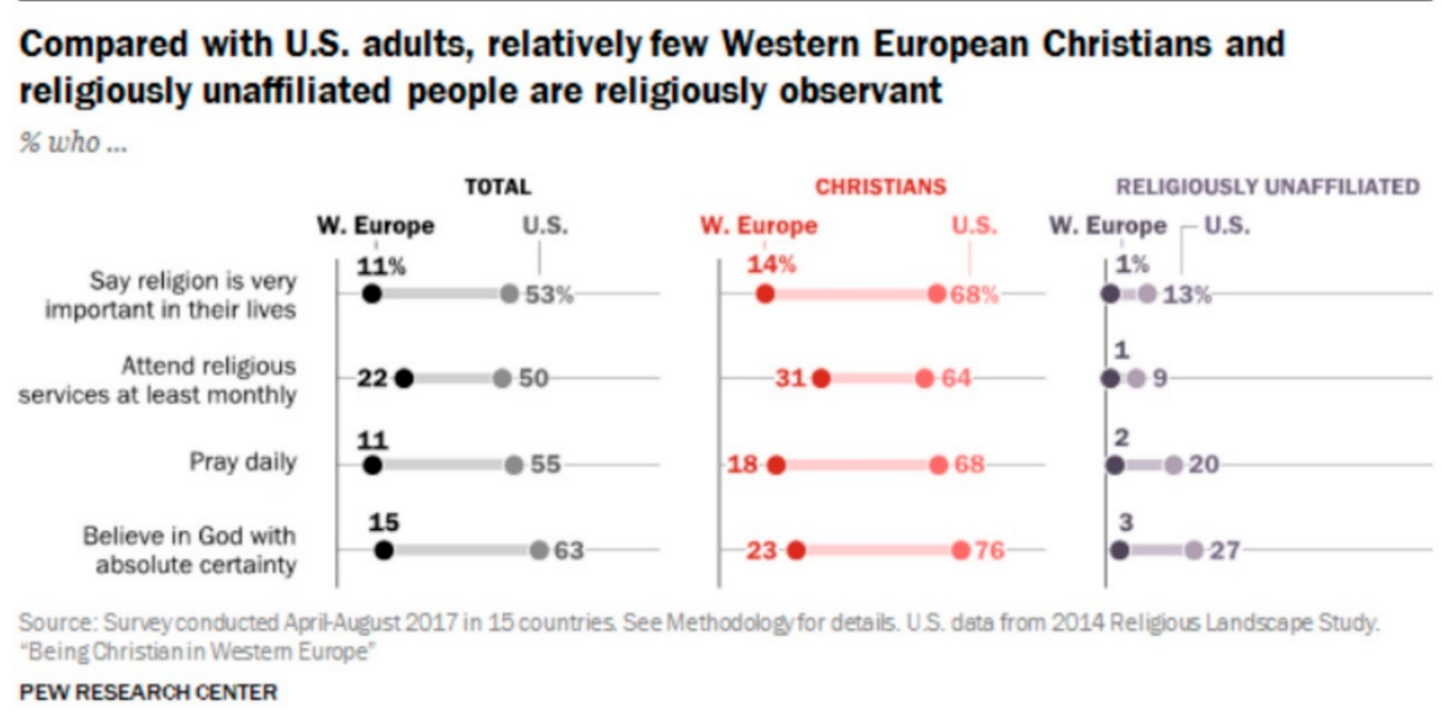

Figure 1. Religious observance among Christians and the Unaffiliated in Western Europe and the U.S. (Sahgal 2018).

\section{Pansacramentalism and Interreligious Theology}

The contemporary method of interreligious theology and its predecessors described above, and the brief insight into trends among young Nones and Somes, is sufficient for the purposes of this article in making the case for why pansacramentalism, in particular for those who identify with, in some manner, a Christian tradition, serves as a promising starting point for embracing interreligious theology. This section turns to the question of determining sacramental authenticity for interreligious truth-seeking, and to the rationale for incorporating a Lived Religion approach to the encounter with, and study of, the religious other (i.e., for the doing of interreligious theology).

If all things are potentially sacramental, as pansacramentalism espouses, then how ought one to determine whether something is sacramental? Are there limits to pansacramentality? Can suffering be sacramental? If so, can all suffering be sacramental? Was Auschwitz sacramental? The claim of pansacramentalism is not that all things are actually sacramental, but rather all things are potential mediators of the divine in some manner; perhaps something might be interpreted as sacramental in a manner that reveals the terrifying limitations or God (e.g., Auschwitz perhaps exposes the limitations of God to intervene in horrendous human events carried out in the world). ${ }^{22}$ How ought one to construct a criterion or set of criteria upon which something might be determined sacramental? No hard-and-fast answer is offered here, but rather religious traditions ought to look inward to their resources, wisdom, and communities, for meaningful criteria. Thus, no unified agreement will be reached on sacramental authenticity. To provide a sense of what this might mean, I offer an example by drawing on Abraham

22 E.g., one might extract God's limitations (including suffering and pathos) from the powerful witness account Elie Wiesel narrates in his well-known book Night about being imprisoned at Auschwitz: "The SS hanged two Jewish men and a youth in front of the whole camp. The men died quickly, but the death throes of the youth lasted for half an hour. 'Where is God? Where is he?' someone asked behind me. As the youth still hung in torment in the noose after a long time, I heard the man call again, 'Where is God now?' And I heard a voice in myself answer: 'Where is he? He is here. He is hanging there on the gallows" (Wiesel 1969, p. 75; also quoted in Moltmann 1993, p. 274; also quoted in Gustafson 2016a, p. 284). 
Joshua Heschel's theology of divine pathos, theomorphism, and anthropomorphism. Keep in mind, this is but one example of how sacramental authenticity might be gauged. Ultimately such criteria will have to come from within religious traditions, communities, and individuals themselves. Heschel comes out of the Jewish tradition, but the criteria certainly need not come from only Abrahamic traditions. For instance, some might draw on Hinduism's Advaita Vedanta, Buddhism's doctrine of anattā (no-self), Shinto affirmations, Christian virtues, and so on. The idea here is that a criterion or some set of criteria will be useful for determining the sacredness of a thing if all things are deemed potentially sacred. Moreover, when we consider interreligious theology and the increasing comfort of young people to blend multiple traditions, the range from which a community or individual might certainly expand (e.g., hence a Christian might be inspirited by Heschel's Jewish theology of theomorphism, or Jew might be inspired by the Buddhist doctrine of no-self).

In The Prophets, Heschel offers the biblical vision of a God full of pathos. God "does not simply command and expect obedience; He is also moved and affected by what happens in the world, and reacts accordingly" (Heschel 2001, p. 288). Heschel's Biblical God, as full of pathos, is susceptible to being moved and affected by emotion. John Merkle points out that, "While Heschel's philosophical argument for the pathos of God challenges the tradition of classical metaphysical theology ... it is not meant to challenge traditional Jewish understanding" (Merkle 2009, p. 4). By promoting a biblical concept of a God moved by and affected by emotion and suffering, unsurprisingly Heschel has sometimes been accused of anthropomorphizing God due to his alleged casting of human qualities (suffering, emotion, passibility) onto God. Heschel turns this charge on its head by raising the category of theomorphism, which is the casting of Godly qualities onto humans.

In Heschel's view, the prophets of ancient Israel, in proclaiming a God full of pathos, do not anthropomorphize God; rather, they theomorphize humans. ${ }^{23}$ The prophets did not cast imperfect humanly qualities onto a perfect God, but cast perfect Godly qualities onto imperfect humans. For Heschel, virtues such as love, compassion, empathy, and pathos are not first and foremost human qualities, they are first and foremost Godly qualities. Hence, when the prophets speak of God as absolutely selfless and loving,

absolute selflessness and mysteriously undeserved love are more akin to the divine than to the human. And if these are characteristics of human nature, then man is endowed with attributes of the divine. God's unconditional concern for justice is not an anthropomorphism. Rather, man's concern for justice is a theomorphism ... The language of the prophets employed to describe that supreme concern was an anthropomorphism to end all anthropomorphism (Heschel 2001, p. 349). ${ }^{24}$

Heschel defends against the charge of anthropomorphizing God by pointing to the prophets' use of metaphorical theomorphic language. He writes, "to speak about God as if He were a person does not necessarily mean to personify Him, to stamp Him in the image of a person ... The idea of the divine pathos is not a personification of God but an exemplification of divine reality ... It does not represent a substance, but an act or a relationship" (Heschel 2001, pp. 350-51). Heschel's biblical vision of God allows for a mutual interrelation between God and persons. It yields a concept of the sacred (in this case "God") that is dynamic and in relation to people ${ }^{25}$ (i.e., God is capable of change, but God's nature remains immutable). Heschel states: "The divine pathos which the prophets tried to express in many ways was not a name for His essence but rather for the modes of His reaction to Israel's conduct which would change if Israel modified its ways" (Heschel 1951, p. 245).

23 The paragraphs that follow on Heschel's theology of theomorphism are adapted from (Gustafson 2016a, pp. 274, 281-82, 296-97).

24 Also quoted in (Merkle 1985, p. 99).

25 Though Heschel preserves God's immutable nature by positing that just because God is capable of change (in relations to the world and to people) does not entail that God's nature changes. God's nature remains immutable. 
Theomorphism exposes the connection between the sacred as such and the sacred found within the individual person. Given pansacramentalism's vision to find the sacred in all things in a sacramental fashion, the challenge surfaces as to how to determine whether a "thing" is sacramental. Christians might (and perhaps Jews for that matter given Heschel's rigorous Jewish vision of God), as I have argued, employ Heschel's theology of theomorphism as a foundation for the "sacramental robustness" of a particular thing (person, action, experience, etc.). Sacraments communicate the sacred by virtue of the sacred being present within them, and Heschel's theology provides a foundation for thinking about how the sacred is present. Does a thing reflect the sacred, theomorphically or otherwise, in a manner consistent with one's religious tradition (however that might be perceived)? Heschel's theomorphism, and his defense against the charge of anthropomorphism serves as a model for interpreting theomorphic qualities found not just in persons, but in the world. Heschel writes,

The idea of the divine pathos combining absolute selflessness with supreme concern for the poor and the exploited can hardly be regarded as the attribution of human characteristics. Where is the man who is endowed with such characteristics? Nowhere in the Bible is man characterized as merciful, gracious, slow to anger, abundant in love and truth, keeping love to the thousandth generation ... if these are characteristics of human nature, then man is endowed with attributes of the divine. (Heschel 2001, pp. 348-49)

Utilizing theomorphism to determine the "sacramental robustness" of a thing has the advantage of taking the relation between external sanctity and intrasubjective sanctity seriously. Inspired by Perry Schmidt-Leukel's fractal interpretation of religious diversity, I argue that one's intrasubjective sanctity (the sacredness within an individual person) mirrors the sacred itself and the sanctity of the cosmos (Gustafson 2019). Consider a person that works to promote justice, alleviate suffering in the world, and is simply the "sort of person who epitomizes what it means to be a saint" (Campbell and Putnam 2012, p. 620). In so doing, she exhibits theomorphic qualities, or God-formed qualities, in the world. Pansacramentalism posits that she makes the sacred present in the world. Political scientists David E. Campbell and Robert D. Putnam famously refer to this type of person as our "Aunt Susan." They claim that "We all have an Aunt Susan in our lives, the sort of person who epitomizes what it means to be a saint" (Campbell and Putnam 2012, p. 620). They develop their well-known "Aunt Susan Principle on this scenario, and in their formula, Susan's "religious background is different from our own", although for the present argument it need not be. Maybe Susan shares your religious tradition, or perhaps "Aunt Susan is not religious at all. But whatever her religious background (or lack thereof), you know that Aunt Susan is destined for heaven" (Campbell and Putnam 2012, p. 620). The more theomorphic Susan's actions and qualities, I suppose, then the more God-like, and thus the more sacramental, she is. In such a view, Aunt Susan, one might argue, is very theomorphic, or sacramental, in that she exhibits a combination of "absolute selflessness with supreme concern for the poor and the exploited" (Heschel 2001, pp. 348-49). In other words, a useful criterion for determining the sacramental robustness of a thing (in this case, a person's life or actions) is a theomorphic principle that states wherever qualities of the sacred (God-like traits) manifest in the world (e.g., person, action, etc.), the more sacramental that thing is.

An implication of this view is that there can be degrees of sacramentality. Therefore, a "next step" is to determine-rather, it is for religious traditions, communities, and individuals to determine-what qualifies as qualities of the sacred. Perhaps this is where the religions themselves, and their practitioners, offer wisdom. Jews might look to the Hebrew Bible (as Heschel has done), Christians to Jesus, and Muslims to the Qur'an, to determine what qualifies as qualities of the sacred (e.g., compassion, justice, virtue, mercy, love, honesty, courage, wisdom, discernment, etc.). However, given the emergence of interreligious theology, the data for determining the sacramental robustness of a thing can be expanded beyond one's own religious tradition. It is in this respect that the value of Lived Religion surfaces, not only as a frequently employed approach to the academic study of religion and theology but also as a fruitful method for the everyday religious and interreligious experience. For Christians in particular, the category of "sacramentality" might serve as a welcoming gateway to consider seeking 
truth, authenticity, and wisdom in traditions other than their own. If Christians can accept that all things hold the potential to manifest the sacred in some fashion, this unlocks non-Christian traditions as potential avenues for religious truth and experience not previously considered. As such, identifying non-Christian "things" as having some sacramental robustness provides the opportunity-or perhaps mandates-that they be considered in the doing of theology. Hence, such a pansacramental Christian theology then becomes an interreligious theology. ${ }^{26}$

\section{Lived Religion's Contribution to Pansacramental Interreligious Theology}

It is hardly surprising that a pansacramental worldview, which maintains that all things hold the potential to manifest the sacred in some manner, coupled with the doing of theology interreligiously, ${ }^{27}$ resonates with recent data about the nature of contemporary religious identities and is enhanced by the recent trend in the study of religion to emphasize "Lived Religion" (LR) approaches.

LR is about "what people actually believe and do" and is, therefore, "real, particular, and often messy - a far cry from safe or neat accounts contained in textbooks" (Gregg and Scholefield 2015, p. 7) on world religions. This approach, which privileges religion-as-lived over religion-as-preached, investigates religion at the "on the ground" (e.g., in the trenches, on the streets, in homes, offices, and places in between). Such an approach proceeds by examining the various ways communities and individuals demonstrably manifest their religious, spiritual, and secular worldviews and lifeways in their concrete daily lives including the mundane and ordinary. As Meredith McGuire asserts, this approach claims that "individual religious commitment is evidenced less by avowed commitment to and participation in the activities of religious organizations than by the way each person expresses and experiences his or her faith and practice in ordinary places and in everyday moments" (McGuire 2008, p. 213). Furthermore, it rests on the premise that to more fully understand "modern religious lives, we need to try to grasp the complexity, diversity, and fluidity of real individuals' religion-as-practiced, in the context of their everyday lives" (McGuire 2008, p. 213).

In short, LR is the study of religion in the everyday (including family, workplace, and social entanglement), but of course, it includes the examination of religious communities (synagogue, church, mosque, etc.) (Stringer 2015, p. 4). Scholars on the leading edge and formation of LR emphasize the hyper-locality and particularity of "religioning" (the doing of religion). Robert Orsi grounds LR on the principle that religion "cannot be neatly separated from the other practices of everyday life, from the ways that human beings work on the landscape, for example, or dispose of corpses, or arrange for the security of their offspring" (Orsi 1997, pp. 6-7). In a similar fashion, Nancy Ammerman adds that "finding religion in everyday life means looking wherever and however we find people invoking a sacred presence" (Ammerman 2014, pp. 190-91). To be sure, as McGuire sagely counsels, although "studies of religious organizations and movements are still relevant, they cannot capture the quality of people's everyday religious lives. As messy as these lives may be in practice, individuals' lived religions are what really matters to them" (McGuire 2008, p. 213).

26 I have suggested the merit for the consideration of adjusting the universal claims of pansacramentalism to employ non-Christian-centric language to something more neutral, if possible; especially given how imbued the language of sacramentality is with Christianity (and especially Catholicism). Thus, I have suggested the consideration of other terms such as Eliade's "hierophany", "theophany", or perhaps it is best to simply use "sacred." "In this case, pansacramentality might be better labeled as pan-hierophanism or pan-theophanism. In fact, such language is more in keeping with the spirit of practicality, for Eliade used these terms to express his recognition of 'wide-ranging structural similarities across all religions' (Schmidt-Leukel 2017, p. 227). Eliade states, as quoted by Schmidt-Leukel, 'we are faced with a manifestation, vastly different obviously, of the sacred in a fragment of the universe' (Eliade [1939] 1996, p. 463; also quoted in Schmidt-Leukel 2017, p. 227; also quoted in Gustafson 2019).

27 Oddbjørn Leirvik observes, "to be relevant, university theology must relate critically and constructively to the lived diversity of beliefs and practices among European Muslims, and their multifaith surroundings. At first glance, the cues of 'university theology' and 'lived religion' might seem to point in different directions-academic and theoretical versus popular and practical. But just as academic theology may relate dynamically to lived religion, lived religion may have theological implications and even ambitions to influence the way in which theology is done in the academy. This interactive understanding of theology also applies to interreligious ways of doing theology" (Leirvik 2018). 
As noted above, it certainly takes no stretch of the imagination to envision why the spirit of pansacramentalism might easily find common ground with an LR approach. They both emphasize the idea that all places and spaces humans occupy, all experiences humans report, and all practices humans engage not only become fertile ground for genuine sacramental experience, but also serve as the primary object of study for the LR approach in its quest to investigate how people concretely live out their religious identities in the complicated and messiness of the here and now. So, LR serves pansacramentalism by taking seriously the everydayness of lived religious experience and thusly provides potential "data" for sacramental experience. Likewise, interreligious theology, a theological sub-discipline that takes seriously the value of claims from multiple traditions, finds a valuable ally in LR and an avenue through which to receive claims of religious experience worthy of theological digestion.

(Pan)sacramentality correlates with the quest for sacred in the particular and LR is almost hyper-focused on the particular manifestations of religion as carried out by individual people and communities. LR helps to remind the pansacramental theologian to seek beyond neatly sealed or traditional religious boundaries for sacramental experience. It calls forth the sacramental potential of all things. Again, McGuire is instructive by pointing out that "when we no longer assume that individuals' religions can be equated with their religious affiliation or encompassed by their membership in a religious organization, then we realize that we must ask different questions" (McGuire 2008, p. 213). For the theologian interested in pansacramentalism and particularity, these different questions include the potential sacred (sacramental) nature of all things, regardless of how mundane, ordinary, or boring they may appear.

Such emphasis on the everyday particularity and the lived religion of individuals help illuminate and sharpen the complexity of the growing trend, especially among younger people, to report complicated, mixed, multiple, dual, and hybrid religious identities. As noted above, there are several reasons that contribute to this trend, however, the role that LR and interreligious pansacramental theology might play is to take these religious identities seriously and ask what they might mean not only for understanding and the study of the category of "religion", but also for understanding how individual religious lives (especially experience) relate to traditions as historically preached and preserved. Might pansacramentalism, interreligious theology, and LR serve some liberative function not only to descandalize such complicated religious identities, but also to recognize how religious identities, especially in the construction of theological worldviews and ways of life, intersect with so-called non-religious influences on identity such as language, culture, age, class, gender, race, and so on. Above all, an overarching aim here is not only to achieve a more accurate and nuanced view of how people religiously (or non-religiously) identify, but to ever-strive for greater clarity of truth-seeking and knowledge generation in the academic fields of the study of religion, interreligious studies, and theological studies.

Of course, there are limits and challenges to the LR method, which remain present to pansacramental interreligious theology as well. There is the concern of over-normalizing the particular lived reality of religious experience to the determent of historical traditions and to the point of the latter withering away. How does religion-as-preached and religion as historically and institutionally founded retain a place of some authority in the study of LR? Another legitimate concern, as mentioned above, consists in determining genuine and authentic sacramental experience so as not to suggest that simply all things are of sacred significance (and perhaps understood as normatively "good"). ${ }^{28}$ Certainly, there ought to be room to call out harmful and oppressive experiences and actions as just that without deeming them sacred and therefore "good." The example from Heschel was but one attempt to draw on a particular tradition to determine a criterion upon which a tradition or an individual

28 Make no mistake. The claim here is not that somehow, for example, Auschwitz was a divine good and ought to have happened. Of course not. 
might employ in order to deem something as sacramental. Of course, others may look to their own tradition(s), histories, and experiences to generate such criteria for sacramental authenticity, or perhaps they will draw on several in the spirit of interreligious theology. Ultimately, perfect and unified criteria will not be agreed upon. However, that hardly seems problematic. Might we find some comfort in simply resting in the uncertainty that characterizes all of life? For such an attitude, we are already experts—especially those who have lived a little—for truly all of life is ultimately uncertain.

Funding: This research received no external funding.

Conflicts of Interest: The author declares no conflict of interest.

\section{References}

Ammerman, Nancy T. 2014. The 2013 Paul Hanly Furfey Lecture: Finding Religion in Everyday Life. Sociology of Religion 75: 189-207. [CrossRef]

Brierley, Michael W. 2004. Naming a Quiet Revolution: The Panentheistic Turn in Modern Theology. In In Whom We Live and Move and Have Our Being: Panentheistic Reflections on God's Presence in a Scientific World. Edited by Philip Clayton and Arthur Peacocke. Grand Rapids: Eerdmans, pp. 1-15.

Buber, Martin. 1966. Symbolic and Sacramental Existence. In The Origin and Meaning of Hasidism. Translated by Maurice Friedman. New York: Harper \& Row.

Campbell, David E., and Robert D. Putnam. 2012. America's Grace: How a Tolerant Nation Bridges Its Religious Divides. Political Science Quarterly 126: 611-40. [CrossRef]

Cornille, Catherine. 2019. Meaning and Method in Comparative Theology. Hoboken: Wiley Blackwell.

Drescher, Elizabeth. 2016. Choosing Our Religion: The Spiritual Lives of America's Nones. New York: Oxford University Press.

Eliade, Mircea. 1996. Patterns in Comparative Religion. Lincoln: University of Nebraska Press. First published 1939.

Flory, Richard. 2017. The Changing Nature of America's Irreligious Explained. The Conversation. January 23. Available online: http://theconversation.com/the-changing-nature-of-americas-irreligious-explained-71066 (accessed on 16 May 2019).

Gregg, Stephen E., and Lynne Scholefield. 2015. Engaging with Living Religion: A Guide to Fieldwork in the Study of Religion. London: Routledge.

Gustafson, Hans. 2013. Pansacramentality as a New Model for the God-World Relationship in Panentheism. Paper presented at the Upper Midwest Regional Meeting of the American Academy of Religion, St. Paul, MN, USA, April 6.

Gustafson, Hans. 2016a. Finding All Things in God: Pansacramentalism and Doing Theology Interreligiously. Eugene: Pickwick.

Gustafson, Hans. 2016b. Is Transreligious Theology Unavoidable in Interreligious Theology and Dialogue? Open Theology 2: 248-60. [CrossRef]

Gustafson, Hans. 2019. The Silent Witness of Intuition: Pansacramentality, Interreligious Encounter, and a Fractal Interpretation of Religious Diversity. In New Paths for Interreligious Theology: Perry Schmidt-Leukel's Fractal Interpretation of Religious Diversity. Edited by Alan Race and Paul Knitter. Maryknoll: Orbis Books.

Hedges, Paul. 2017a. Comparative Theology: A Critical and Methodological Perspective. Leiden: Brill.

Hedges, Paul. 2017b. Multiple Religious Belonging after Religion: Theorising Strategic Religious Participation in a Shared Religious Landscape as a Chinese Model. Open Theology 3: 48-72. [CrossRef]

Heschel, Abraham Joshua. 1951. Man Is Not Alone: A Philosophy of Religion. New York: Farrar, Straus \& Young. Heschel, Abraham Joshua. 2001. The Prophets. New York: Perennial Classics.

Inge, William Ralph. 1948. Christian Mysticism. London: Methuen.

Knight, Christopher C. 2001. Wrestling with the Divine: Religion, Science, and Revelation. Minneapolis: Fortress Press.

Leirvik, Oddbjørn. 2018. Interreligious University Theologies, Christian/Islamic. Islam and Christian-Muslim Relations 29: 509-23. [CrossRef]

Martin, Jerry L. 2016. Is Transreligious Theology Possible? Special Issue. Open Theology 2.

Martos, Joseph. 2001. Doors to the Sacred: A Historical Introduction to Sacraments in the Catholic Church, Revised Edition. Liguori: Liguori/Triumph.

McGuire, Meredith B. 2008. Lived Religion: Faith and Practice in Everyday Life. New York: Oxford University Press. 
Meir, Ephraim. 2015. Interreligious Theology: Its Value and Mooring in Modern Jewish Philosophy. Berlin: DeGruyter. Merkle, John C. 1985. The Genesis of Faith: The Depth Theology of Abraham Joshua Heschel. New York: Macmillan. Merkle, John C. 2009. Approaching God: The Way of Abraham Joshua Heschel. Collegeville: Liturgical Press. Moltmann, Jürgen. 1993. The Crucified God. Minneapolis: Fortress.

Nouwen, Henri. 1994. The Return of the Prodigal Son: A Story of Homecoming. New York: Doubleday.

Orsi, Robert. 1997. Everyday Miracles: The Study of Lived Religion. In Lived Religion in America: Toward a History of Practice. Edited by David D. Hall. Princeton: Princeton University Press.

Panentheism. n.d. The Oxford Dictionary of the Christian Church. Edited by F. L. Cross and E. A. Livingstone. Oxford Reference Online. Oxford: Oxford University Press. Available online: https://www.oxfordreference.com/ view/10.1093/oi/authority.20110803100303684 (accessed on 18 June 2019).

Pew Research Center. 2018. Being Christian in Western Europe. Pew Research Center, May 29. Available online: http://assets.pewresearch.org/wp-content/uploads/sites/11/2016/04/Religion-in-EverydayLife-FINAL.pdf (accessed on 8 April 2019).

Sahgal, Neha. 2018. 10 Key Findings about Religion in Western Europe. Pew Research Center, May 29. Available online: https://www.pewresearch.org/fact-tank/2018/05/29/10-key-findings-about-religion-inwestern-europe/ (accessed on 27 June 2019).

Schmidt-Leukel, Perry. 2009. Transformation by Integration: How Inter-Faith Encounter Changes Christianity. London: SCM Press.

Schmidt-Leukel, Perry. 2015. Interreligious Theology: The Future Shape of Theology. Paper presented at Five-Part Lecture Series Presented as the Gifford Lectures at the University of Glasgow, Glasgow, UK, October 13-21.

Schmidt-Leukel, Perry. 2017. Religious Pluralism and Interreligious Theology: The Gifford Lectures-An Extended Edition. Maryknoll: Orbis.

Smith, Wilfred Cantwell. 1989. Towards a World Theology. Maryknoll: Orbis. First published 1981.

Smith, Wilfred Cantwell. 2001. The Christian in a Religiously Plural World. In Christianity and Other Religions. Edited by John Hick and Brian Hebblethwaite. Oxford: Oneworld.

Stringer, Martin D. 2015. Lived Religion and Difficult Conversations. Birmingham Conversations of the Faith, Neighbors, Changemakers Collaboration. 4. Available online: http://www.fncbham.org.uk/wp-content/uploads/ 2015/05/Lived-Religion-and-Difficult-Conversations.pdf (accessed on 25 July 2018).

Ward, Keith. 1994. Religion and Revelation: A Theology of Revelation in the World's Religions. New York: Oxford University Press.

Ward, Keith. 1996. Religion and Creation. New York: Oxford University Press.

Ward, Keith. 1998. Religion and Human Nature. New York: Oxford University Press.

Ward, Keith. 2000. Religion and Community. Oxford: Clarendon Press.

Ward, Keith. 2002. The Importance of Liberal Theology. In The Future of Liberal Theology. Edited by Mark D. Chapman. Aldershot: Ashgate Press.

Ward, Keith. 2004. The World as the Body of God: A Panentheistic Metaphor. In In Whom We Live and Move and Have Our Being. Edited by Philip Clayton and Arthur Peacocke. Grand Rapids: Eerdmans, pp. 62-72.

Ward, Keith. 2007. Liberal Theology and the God of Love. In The God of Love and Human Dignity: Essays in Honour of George M. Newlands. Edited by Paul Middleton. London: T \& T Clark.

Ward, Keith. 2008. Religion and Human Fulfilment. London: SCM Press.

Wiesel, Elie. 1969. Night. New York: Avon.

(C) 2019 by the author. Licensee MDPI, Basel, Switzerland. This article is an open access article distributed under the terms and conditions of the Creative Commons Attribution (CC BY) license (http://creativecommons.org/licenses/by/4.0/). 